\title{
KEANEKARAGAMAN IKAN DI DANAU SENTANI
}

\author{
Lismining Pujiyani Astuti"), Chairulwan Umar"), dan Andri Warsa*) \\ ") Peneliti padaLoka Riset Pemacuan Stok Ikan, Jatiluhur-Purwakarta
}

\begin{abstract}
ABSTRAK
Danau Sentani terletak di Kabupaten Jayapura Propinsi Papua dengan luas 9.630 ha yang berfungsi sebagai tempat rekreasi, transportasi, kegiatan perikanan, dan upacara adat. Danau ini mempunyai keanekaragaman ikan baik yang asli (indigenous spesies) yaitu gete-gete (Apogon weichmani, Apogon beauforti), gabus (Oxyeoelotris lineolatus), gabus merah (Ophiocara aporos), sembilang (Hemipimelodus velutinus), rainbow (Chilaterina sentaniensis, Glossolepis indicus), gastor (Channa sp.) maupun introduksi yaitu nila (Tilapia nilotica), mas (Cyprinus carpio), tawes (Puntius gonionotus), tambakan (Helostoma temmincki), mata merah (Puntius orphoides), sepat (Trichogaster pectoralis), mujair (Tilapia mussambica), dan nilem (Osteochillus haselti). Ikan hiu gergaji (Pristis microdons) adalah ikan hiu air tawar yang merupakan ikan asli Danau Sentani yang saat ini tidak pernah dijumpai lagi. Ikan introduksi yang mampu berkembang pesat adalah tambakan, mujair, mata merah, dan sepat siam.
\end{abstract}

\section{KATA KUNCl: keanekaragaman ikan, Danau Sentani, Papua, perairan umum daratan}

\section{PENDAHULUAN}

Keanekaragaman hayati merupakan istilah yang digunakan untuk menerangkan keanekaragaman ekosistem dan berbagai bentuk variabilitas hewan, tumbuhan, dan jasad renik di alam. Dengan demikian, keanekaragaman hayati mencakup keanekaragaman ekosistem (habitat), jenis (spesies), dan genetic (Dahuri, 2003 dalam Pusat Riset Perikanan Tangkap, 2005). Menurut UndangUndang Nomor Tahun 1990, sumber daya alam hayati adalah unsur-unsur di alam yang terdiri atas sumber daya alam nabati (tumbuhan) dan sumber daya alam hewani (satwa) yang bersama dengan unsur non hayati di sekitar secara keseluruhan membentuk ekosistem. Indonesia merupakan negara megabiodiversiti No.2 setelah Brazil yang memiliki 1.300 jenis ikan air tawar dengan kepadatan 0,72 jenis per $1.000 \mathrm{~km}^{2}$. Habitat yang kaya ikan air tawar meliputi sungai-sungai, rawarawa gambut, dan danau-danau (Wargasasmita, 2002).

Daerah Papua dengan uas $416.000 \mathrm{~km}^{2}$ dengan jumlah penduduk $\pm i, 2$ juta jiwa, dan $60 \%$ tinggal di daerah pedalaman dan kekurangan protein hewani. Luas perairan umum di daerah papua diperkirakan seluas 515.000 ha, terdiri atas danau, rawa, telaga, dan sungai (Sunyata, 1981). Pada umumnya perairan umum di Irian Jaya dihuni oleh ikan. Secara administrasi, Danau Sentani terletak di Kabupaten Jayapura Propinsi Papua. Secara geografis, terletak $2^{\circ} 33^{\prime}-2^{\circ} 41^{\prime} \mathrm{S}, 140^{\circ} 23^{\prime}-$ $140^{\circ} 38^{\prime} \mathrm{E}, 12 \mathrm{~km}$ timur laut Jayapura, dengan luas 9.630 ha pada ketinggian 70 sampai dengan $90 \mathrm{~m}$ di atas permukaan laut (Gambar 1). Luas daerah tangkapan hujan sekitar $600 \mathrm{~km}^{2}$ dan dengan oulet pada 1 aliran sungai yaitu Sungai Jafuri yang merupakan anak Sungai Tami yang bermuara ke Samudra Pasifik dekat perbatasan Papua New Guinea. Danau Sentani mendapat suplai air dari sekitar 32 sumber mata air pegunungan. Danau mempunyai kedalaman maksimum $52 \mathrm{~m}$ dengan rata-rata curah hujan tahunan $2 \mathrm{~m}$. Berdasarkan pada survei tahun 1970 sampai dengan 1971, 1984, dan 1987 tidak terdapat stratifikasi termal pada danau ini dengan suhu 29 sampai dengan $32^{\circ} \mathrm{C}$ sampai dengan kedalaman $10 \mathrm{~m}, \mathrm{pH}$ permukaan 6,2 sampai dengan 6,8 (Moore et al., 2005).

Danau Sentani merupakan satu kesatuan dengan cagar alam pegunungan Cycloops (Jayapura) oleh pemerintah Kota Jayapura telah diprogramkan sebagai obyek wisata, pusat penelitian, dan pengembangan ilmu pengetahuan (Kompas, 2002). Pada tahun 1999 cagar alam tersebut telah ditetapkan sebagai laboratorium alam, tempat pengembangan dan pengkajian lingkungan hidup. Cycloops mengandung banyak unsur pegunungan yang endemik antara lain 273 jenis burung, 86 jenis mamalia, serta 4.500 jenis tumbuh-tumbuhan. Di daerah tersebut terdapat berbagai jenis tumbuhan, hewan endemik dan serangga khas Papua (Kompas, 2001).

Danau Sentani dimanfaatkan masyarakat sekitar sebagai sumber pemenuhan kebutuhan hidup mereka terutama ikan sebagai sumber protein hewani, perikanan tangkap dan budi daya, tempat upacara adat, tempat rekreasi, dan pembangkit listrik. Masyarakat sekitar Sentani sangat bergantung pada Danau Sentani sehingga kelestarian harus dijaga semaksimal mungkin. 


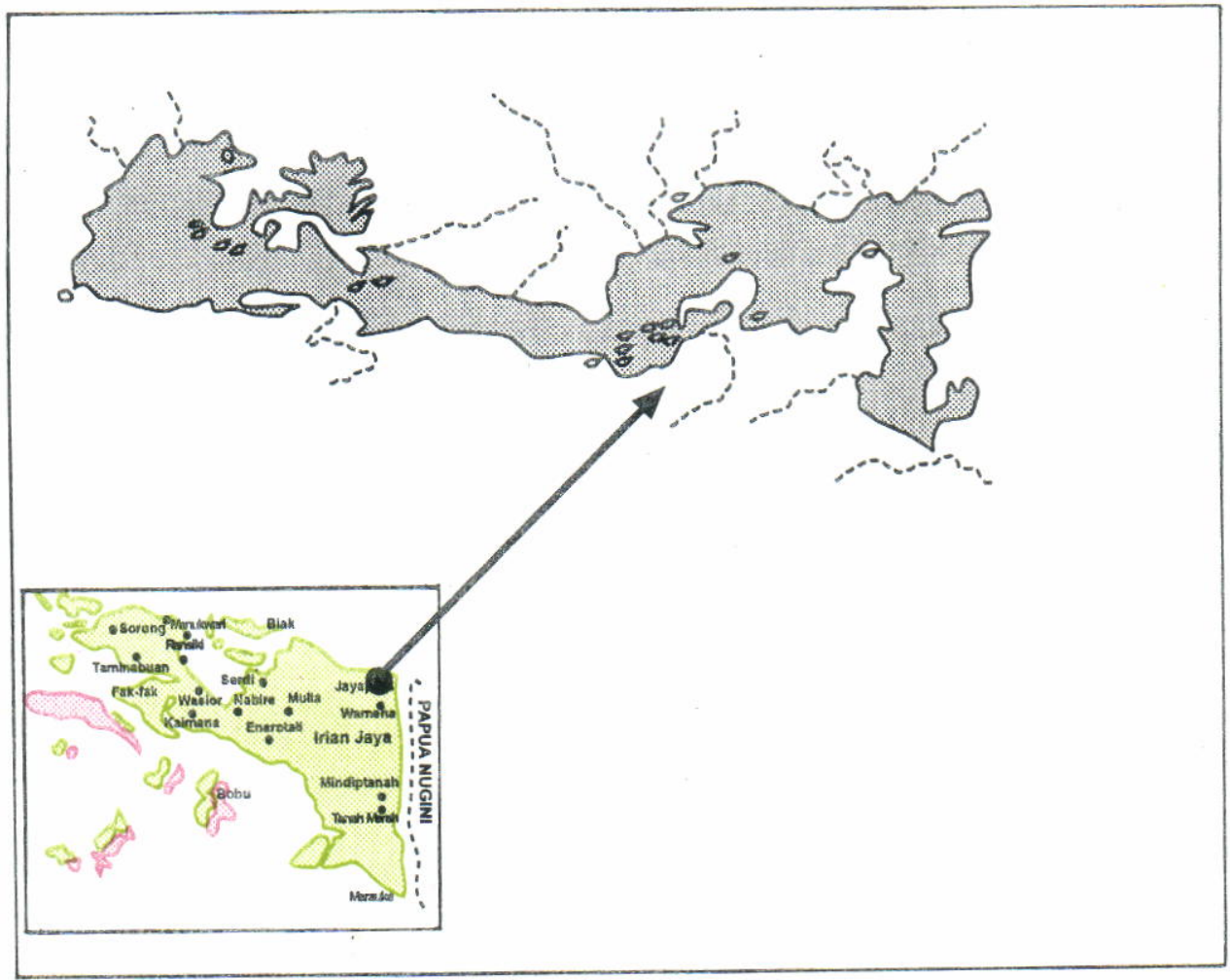

Gambar 1 .

Peta Danau Sentani.

\section{KEANEKARAGAMAN IKAN DI DANAU SENTANI}

Pada penelitian-penelitian terdahulu di Danau Sentani terdapat 33 spesies ikan: 12 spesies merupakan spesies asli, 8 spesies anadromus, dan 13 spesies hasil introduksi (Moore, et al., 2005). Di danau ini sedikitnya terdapat 5 jenis ikan endemik Papua yaitu Anus sp., Neosilirus novaegunineae, Chilatenina sentaniensis, Glossolepis incisus, dan Glossogobius koragensis yang 2 diantaranya yaitu $N$. novaeguineae dan $G$. incisus hanya terdapat di Danau Sentani. Ikan hiu gergaji (Pritis microdon) juga terdapat di danau ini (Gambar 2) (Anonim, 2005a). Pada umumnya perairan umum di Papua dihuni oleh ikan buas (predator) dan ikan laut yang telah beradaptasi dengan perairan tawar. Hasil penelitian tahun 2005 menunjukkan bahwa jenis ikan yang banyak terdapat di Danau Sentani adalah jenis ikan karnivora, karena dari hasil pengamatan food habits menunjukkan bahwa makanannya adalah udang kecil dan ikan-ikan kecil.

Keanekaragaman fauna ikan pada saat ini disebabkan oleh beberapa faktor:

1. Kejadian atau perubahan-perubahan geologi yang menyebabkan hilang atau timbul hubungan-hubungan antara pulau di Indonesia dengar، Benua Asia atau Australia.
2. Terjadinya pemindahan jenis-jenis ikan antar pulau dan pemasukkan jenis-jenis baru dari luar negeri oleh manusia.

3. Masuknya jenis-jenis ikan laut ke perairan tawar melalui sungai-sungai (Ondara, 1981).

Ikan hiu gergaji (Pritis microdon) adalah jenis ikan endemik yang terdapat di Danau Sentani dan satu-satunya jenis hiu air tawar di dunia yang keberadaannya hampir punah. Ikan hiu ini termasuk jenis ikan yang dilindungi peraturan perundang-undangan di Indonesia yaitu dari SK Mentan No.716/Kpts/Um/10/80 Tahun 1999 tentang pengawetan jenis tumbuhan dan satwa. Ada beberapa hal yang dianggap sebagai penyebab punah ikan tersebut antara lain penangkapan yang berlebih, pencemaran perairan, penggunaan gill net (jaring insang) yang diintrodusir di Danau Sentani pada tahun 1969 yang bertujuan untuk peningkatan ekonomi nelayan, namun kurang memperhatikan kelestarian alam. Pada permulaan tahun 1969 sampai dengan 1971 penggunaan gill net mampu menangkap 151 ekor hiu Sentani (Pristis microdon) tetapi tahun 1974 hiu Sentani yang tertangkap hanya 1 ekor dan tahun-tahun berikut tidak pernah ada lagi. Berarti penggunaan gill net telah menyebabkan kepunahan hiu Sentani (Sunyata, 1981). 


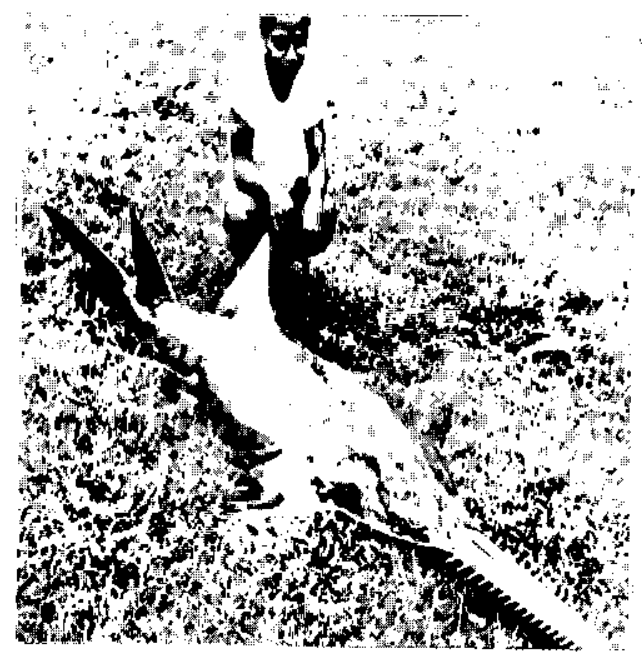

Gambar 2. Hiu gergaji Danau Sentani dengan panjang $2 \mathrm{~m}$ yang tertangkap tahun 1962 (Anonim, 2005b).

Beberapa faktor yang menyebabkan menurunnya jumlah jenis ikan antara lain:

1. Degradasi dan kepunahan habitat, seperti ada pembangunan bendungan.

2. Pencemaran, seperti limbah.

3. Introduksi ikan asing.

4. Eksploitasi komersial, jenis ikan hias.

5. Persaingan penggunaan air.
6. Perubahan iklim global (global climate change) yang merupakan ancaman terhadap kelangsungan hidup ikan (Moyle \& Leydi, Allan \& Flecker dalam Wargasasmita, 2002).

Bebarapa jenis ikan asli (indigenous species) Danau Sentani yang dominan seperti di Tabel 1 dan Gambar 3.

Tabel 1. Ikan asli Danau Sentani

\begin{tabular}{|c|c|c|}
\hline Nama Lokal & Nama Tlinain & Fomiff \\
\hline Seli/Sembilang & Hemipimelodus velutinus & Tachysuridae \\
\hline Gete-gete & Apogon wichmani & Apogonidae \\
\hline & Apogon beauforti & Apogonidae \\
\hline Kaskado/hewu & Chilaterina sentaniensis & Atherinidae \\
\hline /rainbow & Glossolepis indicus & Atherinidae \\
\hline Gabus merah & Ophiocara aporos & Eleotridae \\
\hline Gabus hitam & Oxyeoelotris lineolatus & Eleotridae \\
\hline Gastor & Channa sp. & Channidae \\
\hline
\end{tabular}

Selain ikan-ikan asli Danau Sentani, terdapat pula ikan-ikan yang pernah ditebar di Danau Sentani. (Tabel 2).
Jenis ikan tebaran yang dapat berkembang biak dengan pesat adalah tambakan, lele, mujair, mata merah, dan sepat siam. Sedangkan ikan mas dan

Tabel 2. Ikan tebaran di Danau Sentani

\begin{tabular}{|c|c|}
\hline Nama Lokar & Nama ITriat \\
\hline Mas & Cyprinus carpio \\
\hline Tawes & Puntius gonionotus \\
\hline Mata merah & Puntius orphoides \\
\hline Tambakan & Helostoma temmincki \\
\hline Sepat siam & Trichogaster pectoralis \\
\hline Gurami & Osphronemus goramy \\
\hline Mujair & Tilapia Mussambica \\
\hline Nila & Tilapia nelotica \\
\hline Nilem & Osteochillus haselti \\
\hline+ & Clarias batracus \\
\hline
\end{tabular}



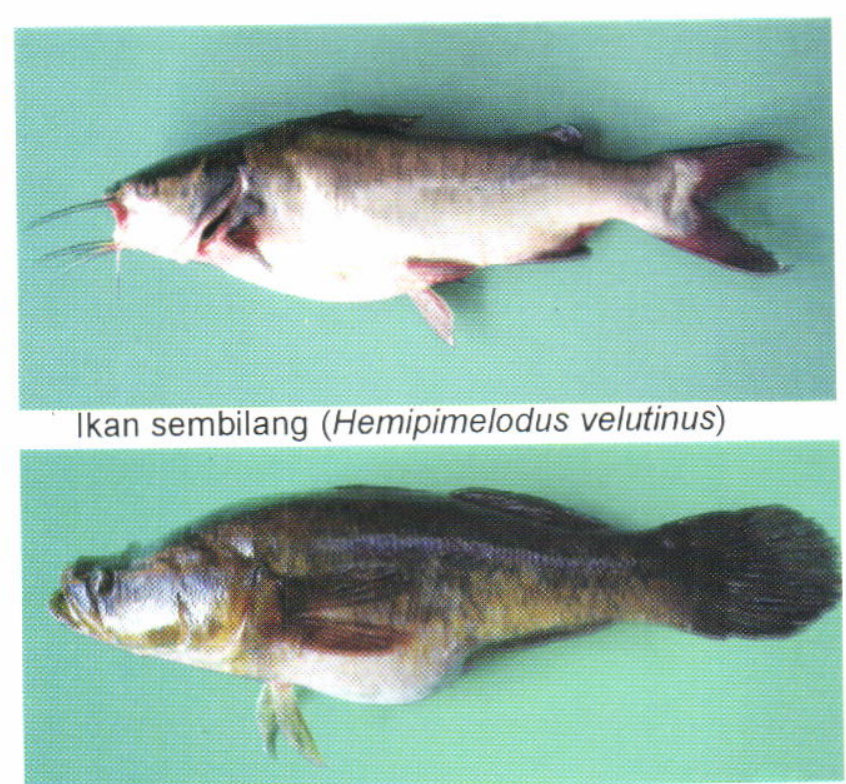

Ikan gabus hitam (Oxyeoelotris lineolatus)
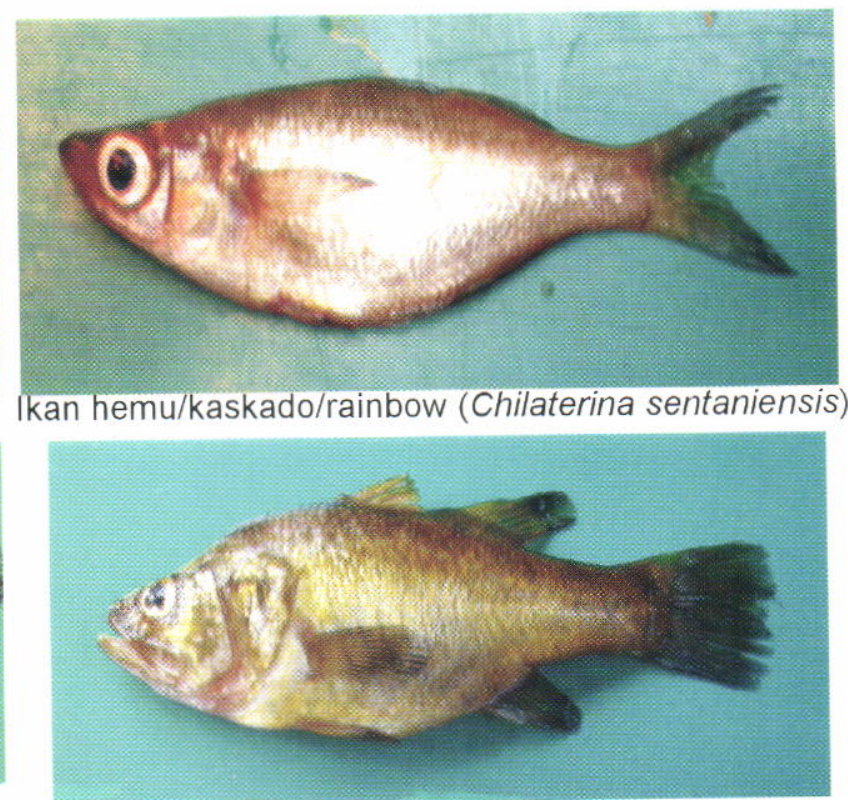

Ikan gete-gete (Apogon wichmani)

Gambar 3. Beberapa jenis ikan asli yang ditemukan di Danau Sentani.

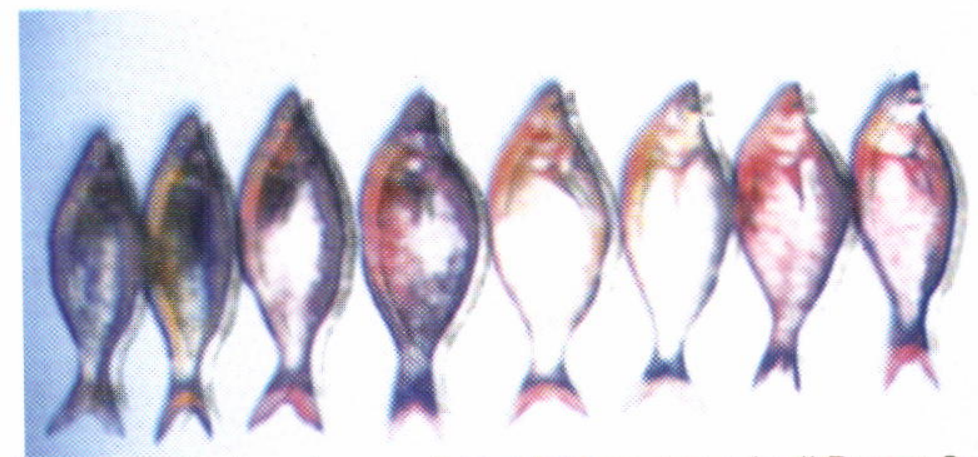

Gambar 4. Berbagai warna ikan rainbow yang ada di Danau Sentani.

tawes meskipun dapat tumbuh besar tetapi jika dilihat dari popiulasi tidak dapat berkembang biak.

Ikan rainbow di Danau Sentani sangat banyak dan kecil-kecil serta indah dengan corak warna yang berbeda yaitu merah, kuning keemasan, dan hitam perak sehingga berpotensi sebagai ikan hias. (Gambar 4).

\section{PERAN SERTA MASYARAKAT DALAM PENGELOLAAN SUMBER DAYA PERIKANAN}

Masyarakat sekitar Danau Sentani bertempat tinggal di bagian pesisir danau maupun pulau-pulau kecil di tengah danau. Masyarakat memanfaatkan danau ini untuk menangkap ikan, menokok sagu yang tumbuh di pesisir danau. Terdapat kearifan masyarakat setempat dalam pengelolaan sumber daya perairan dan perikanan, yaitu aturan-aturan yang sudah ada sejak nenek moyang mereka. Aturan tersebut tidak boleh menangkap ikan pada wilayah tertentu pada waktu tertentu dengan pembentukan tanda larangan. Dan juga ada batasbatas penangkapan menurut adat dengan luas bervariasi dan penangkapan tersebut tidak boleh melanggar batas wilayah lain.

\section{KEANEKARAGAMAN HAYATI LAIN DI DANAU SENTANI}

Vegetasi yang tumbuh sampai dengan kedalaman $6 \mathrm{~m}$ adalah Hydrilla sp., Elodea, Ceratophyllum, Potamogeton, dan Valisineria. Pada bagian yang lebih dangkal ditumbuhi oleh Nympahea dan tumbuhan terapung seperti pistia, lemna, dan Eichornia crassipes. Eceng gondok bukan vegetasi asli dari Danau Sentani, gulma ini dijumpai sekitar tahun 1977 (Sunyata, 1981). Berdasarkan pada hasil penelitian tahun 2005, tumbuhan air baik tenggelam dan mengapung antara lain Hydrilla verticillata, Eichornia crassipes (eceng gondok), Nymphoides sp. (teratai), 


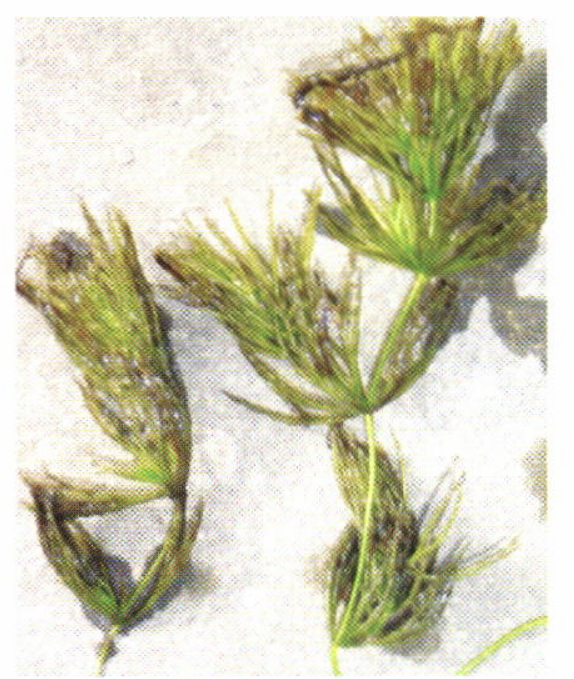

Ceratophylum demersum

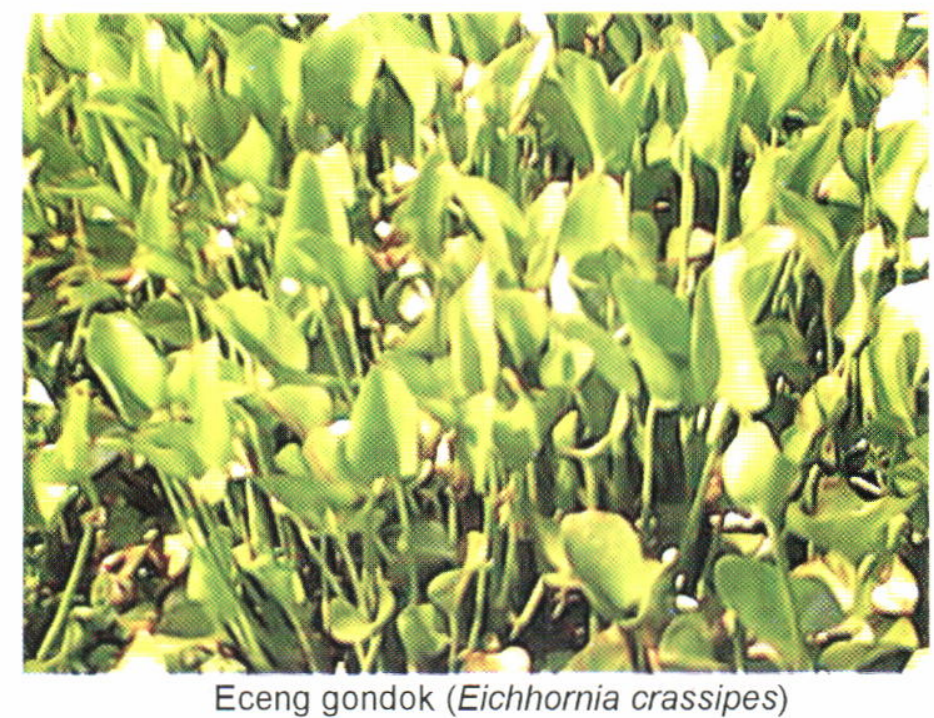

Tanaman air di Danau Sentani.
Impomoea aquatica (kangkung), Ceratophylum demersum, Potamogeton malainus, Vallisneria america, dan Myriophyllum brasiliense (Gambar 5). Menurut Haslam dalam Kovaks (1992) suatu perairan yang banyak ditumbuhi Ceratophyllum demersum mempunyai status eutrofik (kaya nutrisi).

Tanaman lain yang ditemukan terutama di pinggiran danau adalah tanaman pandan dan sagu. Tanaman pandan ini dimanfaatkan penduduk sekitar untuk membuat kerajinan seperti topi dan tikar. Tanaman sagu diambil sagu untuk konsumsi. Sagu merupakan makanan pokok penduduk Papua

Krustacea yang terdapat di Danau Sentani adalah udang galah (Macribrachium roenbergii) dan Macribrachium lar serta Caridina nilotica. Moluska yang ada yaitu Poludonus sp. dan Lamellidens sp. (Sunyata, 1981). Bentos merupakan fauna air yang berada di dasar perairan atau yang menempel pada bebatuan. Pada penelitian tahun 2005 ditemukan beberapa jenis bentos yaitu Physa, Littorina, Campeloma, dan Tarebia dari kelas Gastropoda; Mysis dari kelas Crustacea, dan Chironomus dan Spaniotoma dari famili Tipulidae. Ada sejenis bentos, yang oleh masyarakat setempat disebut bila digunakan untuk konsumsi.

Organisme plankton yang terdapat di Danau Sentani 79 genera plankton yang terdiri atas 49 genera fitoplankton dari kelas Chlorophyceae (21 genera), Cyanophyceae (11 genera), Bacillariophyceae (12 genera), dan Dinophyceae, (5 genera). Fitoplankton yang dominan ditemukan antara lain Ankistrodesmus sp., Chlorella sp., Spirullina sp. (Chlorophyceae), Lyngbya sp.,
Merismopedia sp., Oscillatoria sp. (Cyanophyceae), Navicula sp., Synedra sp., Tabellaria sp. (Bacillariophyceae); Peridinium sp. (Dinophyceae) serta 30 genera zooplankton dari kelas Rotifera (10 genera), Cladocera (8 genera), Copepoda (3 genera), Protozoa (5 genera), dan Bacteria (4 genera). Zooplankton yang dominan antara lain Keratella sp., Polyanthra sp., Rotifer sp. (Rotifera), Nauplis sp., Ceriodaphnia sp. (Cladocera), Cyclop sp., Diatomus sp. (Copepoda), Vampyrella sp., Glenodinium sp. (Protozoa); Bacterium sp., Sphaerobilus sp. (Bacteria).

\section{KESIMPULAN}

Danau Sentani merupakan salah satu danau di Indonesia yang mempunyai banyak jenis ikan asli (indigenous spesies). Sebagian besar ikan di danau ini merupakan ikan endemik. Salah satu jenis ikan yang tidak pernah dijumpai lagi adalah hiu Sentani (Pristis microdon) yang merupakan satu-satunya jenis hiu air tawar di dunia. Partisipasi dan peran serta masyarakat (kearifan local) merupakan salah satu hal penting dalam pengelolaan sumber daya ikan secara berkelanjutan untuk menghindari dari kepunahan.

\section{DAFTAR PUSTAKA}

Anonim. 2005a. Danau Sentani. Diakses dari http://www.arcbc.org.ph/wetlands/Indonesia/idn _dan_sentani.htm. Tanggal 1 September 2005.

Anonim. 2005b. Foto hiu Sentani. Diakses dari http://www.anri.go.id/Citra_daerah/Papua/kebu dayaan/KIT_1044-62_(61)b.htm. Tanggal 1 September 2005. 
Kovaks, M. 1992. Biological indicators in environmental protection. Ellis Horwood Limited. England.

Moore, J. M., A. Rocchi, \& S. M Renyaan. 2005. The background of Lake Sentani. http://www.hannover. park.org/Canada/Museum larcella/5ref.html. Tanggal 1 September 2005

Ondara. 1981. Beberapa catatan tentang perairan tawar dan fauna ikannya di Indonesia. Prosiding Seminar Perikanan Perairan Umum. Badan Penelitian dan Pengembangan Pertanian. Jakarta. Hal: 13-32.

Pusat Riset Perikanan Tangkap. 2005. Dukungan riset untuk pemanfaatan, pengelolaan, dan pelestarian keanekaragaman hayati ikan di perairan pedalaman wilayah Wallacea. Diakses dari

www. unhasalumninet.com/makalah/Makalah biodiversity Wallacea.doc. Tanggal 16 Agustus 2005.

Sunyata, B. 1981. Status perikanan Irian Jaya. Prosiding Seminar Perikanan Perairan Umum. Badan Penelitian dan Pengembangan Pertanian. Jakarta. Hal: 147-152.

Wargasasmita, S. 2002. Ikan air tawar endemik Sumatera yang terancam punah. Jurnal Iktiologi Indonesia (Indonesian Journal of Ichthyology) Vol.2 (2): 41-49. Masyarakat Iktiologi Indonesia. Bogor. 